\title{
Identification of Stakeholders to Establishing Construction Safety Culture in Indonesia
}

\author{
Yusuf Latief $^{1}$, Akhmad Suraji $^{2}$, Leni Sagita ${ }^{3}$ and Rossy Armyn Machfudiyanto ${ }^{4 *}$ \\ ${ }^{1}$ Professor in Department Civil Engineering Universitas Indonesia \\ ${ }^{2}$ Associate Professor in Department Civil Engineering University Andalas \\ ${ }^{3}$ Lecturer in Department Civil Engineering Universitas Indonesia \\ ${ }^{4} \mathrm{PhD}$ Student in Department Civil Engineering Universitas Indonesia
}

\begin{abstract}
The involvement of the government in terms of occupational safety and health through the laws and regulations issued, it is a reference for the stakeholders in the construction industry in carrying out its role and expected performance of safety and health will be better with the existing laws and regulations. these laws and regulations. However, the reality is not in accordance with expectations. The level of work accidents occurring in the construction industry is still relatively high. This study aims to identify stakeholders in building a safety culture in the construction sector. The method used in this research is using survey questionnaire and interview to safety expert. The result of this research is to build safety culture in construction sector is divided into two external and internal stakeholders where the Minister of Manpower, Director General of Supervision of Labor and Occupational Safety and Health Supervisory Supervisory Director is a stakeholder who has the power and interest that most influence in establishing safety culture in the construction sector
\end{abstract}

\section{Introduction}

Culture is the product of the interaction between human (psychological), work (behavioral), and organization (situational) [1]. Every construction company as a stakeholder in the construction industry has basic assumptions that they find or develop that are deemed legitimate, then taught to new members as a way of looking at, thinking and feeling about the issues of the company [2]. Occupational safety and health culture is part of an offending organizational culture, individuals, occupations and organizations that affect and impact health and safety. Based on the research background, it is known that stakeholders have an influence on safety and health performance. Research on stakeholders related to occupational safety and health culture is needed to know the effect on safety and health performance. The purpose of this study is to find out who are the relevant stakeholders in establishing OSH culture on construction projects

\section{Theory Relationship between Stakeholders and Safety Culture}

The State of Indonesia through the establishment of the National Occupational Safety and Health Council $(\mathrm{DK} 3 \mathrm{~N})$, drafting the vision, mission, policy and strategy of national occupational safety and health. The vision of national occupational safety and health is to realize occupational safety and health as a culture because most accidents are caused by unsafe behavior. [3] through his research introduces Total Safety Culture, where the safety and health culture is the result of a dynamic interaction between 3 factors:

1. People (including community attitudes, beliefs and personalities)

2. Behavior (including safe, risk (unsafe) work practices, such as going beyond the call of duty to interfere with the safety of others)

3. Environment (including equipment, equipment, machinery)

These three factors are called Safety Triads [3]. Factor of people and behavior is a human aspect that less attention than environmental factors. And if one of the above factors change then the other two factors will also change and will impact on can not build a culture of safety and healthy work at work.

\footnotetext{
* Corresponding author: $\underline{\text { rossyarmyn@gmail.com }}$
} 
The substance of the national occupational safety and health policy is to involve further employers, workers and other community organizations in building a culture of occupational safety and health so that it is the responsibility of the parties concerned to their environment. Furthermore, in his book Improving Safety Culture: A Practical Guide, Cooper explained that one of the organizational characteristics that has a good safety and health culture is commitment, leadership, strong senior management involvement in occupational safety and health programs. This can be attributed to research conducted by Moore (1995), that stakeholder analysis is useful for management to better shape organizational performance or help shape a regular environment (safety culture and occupational health factors) that will indirectly improve organizational performance. The creation of effective leadership and governance of the policy becomes part of effective stakeholder management ([4], [5], [6]). Bryson and Crosby in his research say that finding out the problems that occur and possible solutions to problem solving, in this case are issues related to occupational safety and health, are part of the problem, and involving stakeholders in solving the problem is a very important aspect in problem solving. From this we can conclude that stakeholders have a link in terms of building a culture of occupational safety and health.

In his study linked 6 factors affecting occupational safety and health culture. These factors consist of internal and external factors [9], namely:

1. Government Policy

2. Social Influence

3. Industrial environment

4. Internal company

5. Project Conditions

6. Influence Group

While the culture of safety and health in the construction company is separated into 4 (four) cultural levels, namely:
1. Physical culture
2. Cultural behavior
3. Culture of Norms and Management
4. Culture of Ideology

\section{Methodology}

Phase I is conducting observations and interviews with occupational safety and health experts to identify influential stakeholders in building a safety and health culture. Experts who made the respondents amounted to at least 3 people with a minimum of 10 years' experience in the field of occupational safety and health with a minimum education background $\mathrm{S} 1$.

Phase II is a pilot survey, which is checking the results of expert validation stage 1 . This stage uses an open questionnaire with interview techniques. The questionnaire addresses the level of difficulty of variables to understand and the possibilities for improvement and simplification. Experts who made the respondents amounted to at least 6 people with a minimum of 10 years' experience in the field of occupational safety and health with a minimum education background $\mathrm{S} 1$.

Phase III is the stage of data collection to the actual respondents. Respondents were asked to provide an assessment of the level of influence of stakeholders in building a safety and health culture. Respondents at this stage are respondents who are in direct contact with construction activities. The criteria of the respondents in the data collection stage III is a person with a background of $\mathrm{S} 1$ education and work experience related to safety activities in the world of construction

Based on the formulation of the problem described, the research strategy used is survey and case study. Identified stakeholder variables and indicators categorized into 2 categories. Then through structural modeling model obtained interaction pattern of relationship between stakeholder variables with the aim of knowing dominant variable to get strategy in building culture of safety and health work.

\section{Result and Discussion}

\section{Stakeholder mapping}

Stakeholder mapping is a process of grouping stakeholders based on the influence (power) and interests (interest) [8]. This grouping is based on perceptions of respondents who follow this questionnaire. The questionnaire data is attached to the appendix. The principle of stakeholder analysis is to utilize stakeholders who have an impact on the intended purpose by using these stakeholder mapping tools. Attitudes from stakeholders will be influenced by the interests of the objectives so that if there are stakeholders that have an impact on the objectives to be achieved then the stakeholders must be managed.

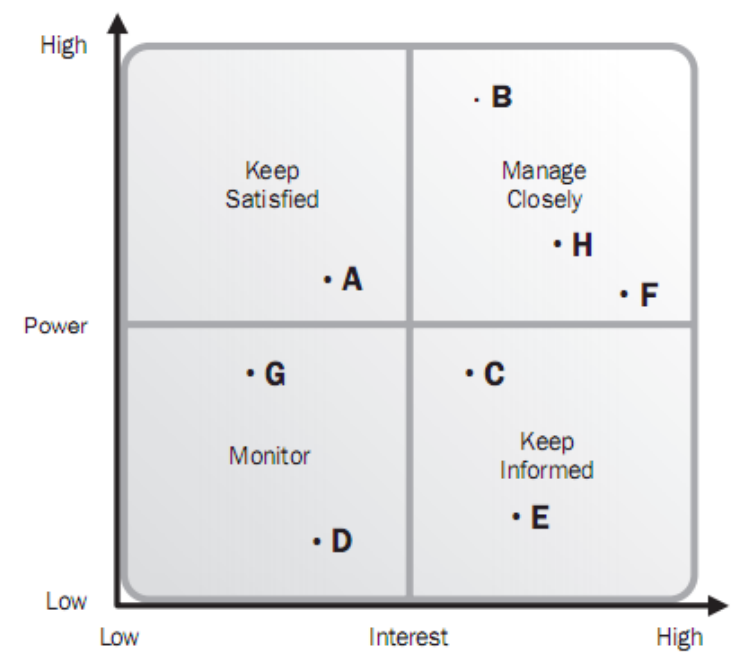

Fig.1 Power Interest Diagram

Source : PMBOK Guide $5^{\text {th }}$ Edition [7]

From the above figures can be seen the grouping of stakeholders based on the influence (power) and interests (interest), that the minister of labor, Director General of PPPK and K3, Director of PNK3, OSH supervisors, Minister of Public Works / Public Relations, Director General Binakon, Committing Officer (PPK) head of the 
Dati I / II disnaker office, Head of K3 section of Dati I / II, Owner, Contractor / Subcontractor, Supervising Consultant, K3 Development Committee, K3 patrol Team, Project Manager, K3 Manager, Occupational Safety and Health K3 priority to manage.

Stakeholders who are influential in establishing $\mathrm{OSH}$ culture are divided into two parts: internal and extralational stakeholders [10] are:

Internal Stakeholder: Owner, Contractor / Subcontractor, Supervisory Consultant, Material / Equipment Vendor, K3 (P2K3) Development Committee, Emergency Response Team (ERT), Fire Rescue Team, Occupational Health Services, K3 Patrol team, Project Manager, OSH Manager, K3 Officer, Occupational Safety, Construction Worker

External Stakeholder: Minister of Manpower, Director General for the Supervision of Labor and Occupational Safety, Director of OSH Supervision, OSH Inspector, National OSH Council, Regional Occupational Safety Council, Health and Safety Service Company (BPK), BPJS, K3 Center, Minister of Public Works / Construction, Structural Official of Echelon I Technical Work Unit, Echelon II Structural Official Technical Work Unit, Direct Head of Work Unit, Kasatker, Commitment Officer, Working Unit of Procurement Unit, Head of I / II, Head of Dati I / II Office, Head of Disnaker Supervision Dati I / II, Non-Governmental Organizations, Civitas Academy / Higher Education, Professional Associations (A2K4), Employers' Association (Gapensi), Labor / Workers Union (SP / SB), Construction Service Development Institution

After expert validation, the results of data processing for the mapping stakeholder process are changed. The original workforce at Low power - High interest, turned into Low power - Low interest, because the main focus of the workforce is wage increases, not safety and health. Construction Services Development Agency (LPJK) also moved from Low power - Low interest to High power Low interest, as the Construction Services Development Agency (LPJK) has the power to issue certification of business entities (SBU) and certification of skilled / skilled workers (SKA / SKT), but K3 is not yet a requirement in issuing this certificate.

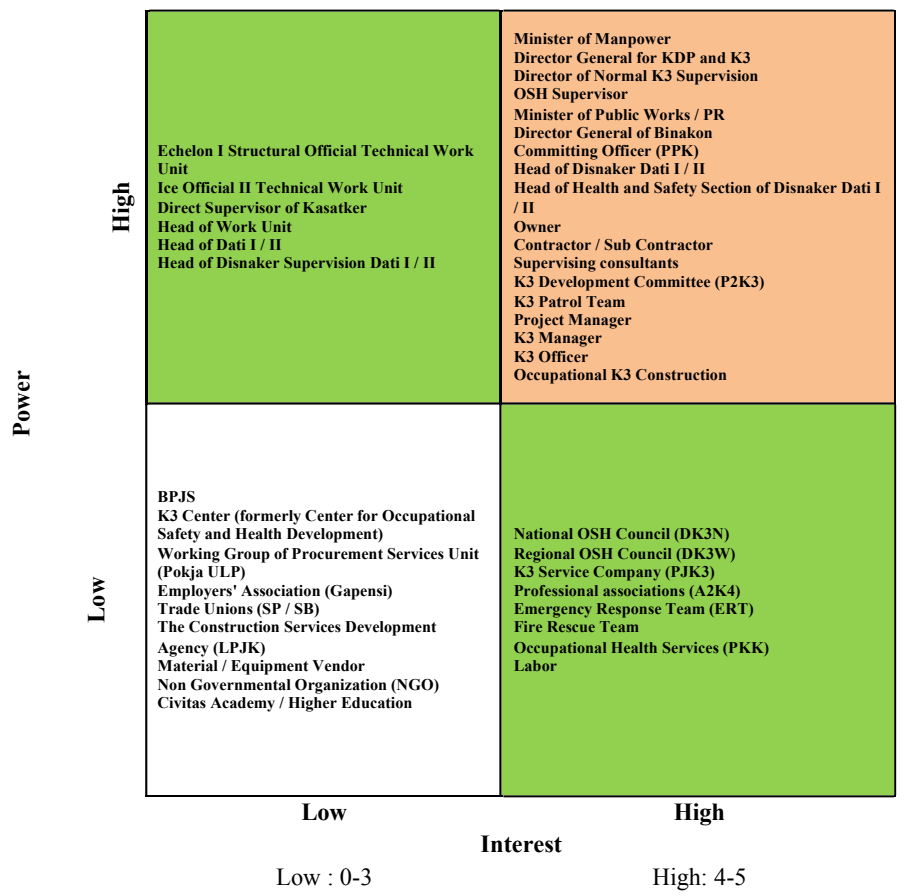

Fig 2. Result of stakeholder mapping

The classification of stakeholders into 4 quadrants, namely:

Table 1. Classification Stakeholder High Power-High Interest

\begin{tabular}{|l|l|}
\hline No & \multicolumn{1}{|c|}{ Classification Stakeholder } \\
\hline 1. & Minister of Manpower \\
\hline 2. & Director of General for KDP and K3 \\
\hline 3. & Director of Normal K3 Supervision \\
\hline 4. & OSH Supervisor \\
\hline 5. & Minister of Public Works / PR \\
\hline 6. & Director General of Construction \\
\hline 7. & Head of Disnaker Dati I / II \\
\hline 8. & $\begin{array}{l}\text { Head of Health and Safety Section of } \\
\text { Disnaker Dati I / II }\end{array}$ \\
\hline 9. & Owner \\
\hline 10. & Contractor / Sub Contractor \\
\hline 11. & $\begin{array}{l}\text { Supervisor Consultant of K3 } \\
\text { Development Committee (P2K3) }\end{array}$ \\
\hline 12. & K3 Patrol Team \\
\hline 13. & Project Manager \\
\hline 14. & K3 Manager \\
\hline 15. & K3 Officer \\
\hline 16. & Occupational K3 Construction \\
\hline
\end{tabular}

Table 2. Classification Stakeholder High Power-Low Interest

\begin{tabular}{|l|l|}
\hline No & \multicolumn{1}{|c|}{ Classification Stakeholder } \\
\hline 1. & $\begin{array}{l}\text { Echelon I Structural Official } \\
\text { Technical Work Unit }\end{array}$ \\
\hline 2. & Ice Official II Technical Work Unit \\
\hline 3. & Direct Supervisor of Kasatker \\
\hline 4. & Head of Dati I / II \\
\hline 5. & $\begin{array}{l}\text { Head of Disnaker Supervision Dati } \\
\text { I II }\end{array}$ \\
\hline 6. & Head of Work Unit \\
\hline
\end{tabular}


Table 3. Classification Stakeholder Low Power-Low Interest

\begin{tabular}{|l|l|}
\hline No & \multicolumn{1}{|c|}{ Classification Stakeholder } \\
\hline 1. & BPJS \\
\hline 2. & $\begin{array}{l}\text { K3 Center (formerly Center for } \\
\text { Occupational Safety and Health } \\
\text { Development) }\end{array}$ \\
\hline 3. & $\begin{array}{l}\text { Working Group of Procurement } \\
\text { Services Unit (Pokja ULP) }\end{array}$ \\
\hline 4. & $\begin{array}{l}\text { Employers association } \\
\text { construction services (Gapensi) }\end{array}$ \\
\hline 5. & Trade Unions (SP / SB) \\
\hline 6. & $\begin{array}{l}\text { The Construction } \\
\text { Development Agency (LPJK) }\end{array}$ \\
\hline 7. & Material / Equipment Vendor \\
\hline 8. & $\begin{array}{l}\text { Non-Governmental Organization } \\
\text { (NGO) }\end{array}$ \\
\hline 9. & Academics / Higher Education \\
\hline 10. & Labor \\
\hline
\end{tabular}

Table 4. Classification Stakeholder Low Power-High Interest

\begin{tabular}{|l|l|}
\hline No & \multicolumn{1}{|c|}{ Classification Stakeholder } \\
\hline 1. & National OSH Council (DK3N) \\
\hline 2. & Regional OSH Council (DK3W) \\
\hline 3. & K3 Service Company (PJK3) \\
\hline 4. & Professional associations (A2K4) \\
\hline 5. & Emergency Response Team (ERT) \\
\hline 6. & Fire Rescue Team \\
\hline 7. & Occupational Health Services (PKK) \\
\hline
\end{tabular}

\section{Conclusion}

Stakeholders in establishing K3 culture in the construction sector is divided into two, namely External Stakeholder: Minister of Manpower, Director General of Labor Supervision and Occupational Safety and Health Supervisory, Supervisory Director of Occupational Health and Safety, OSH Supervisory Board, National OSH Council, Regional OSH Council, Health and Safety Service Company (BPK), BPJS, K3 Center, Minister of Public Works / Bina Konstruksi, Echelon I Structural Official Technical Work Unit, Echelon II Structural Official Technical Work Unit, Direct Head of Satker, Kasatker, Committing Officer, Pokja Unit Procurement Service, Head of Head I / II, Head of Dinas I / II, Kabid Pengawasan Disnaker Dati I / II, Non-Governmental Organizations, Civitas Academy / Higher Education, Professional Associations (A2K4), Employers' Association (Gapensi), Labor / Workers Union (SP / SB), Construction Service Development Institution
Internal Stakeholder: Owner, Contractor / Subcontractor, Supervisory Consultant, Material / Equipment Vendor, K3 Pest Committee (P2K3), Emergency Response Team (ERT), Fire Rescue Team, Occupational Health Services, Patrol K3 team, Project Manager, OSH Manager, Safety Officer, Occupational Safety H3, Labor

The research was funded by the Higher Research Grant of Higher Education for Fiscal Year 2018 No: 1063 / UN2.R3.1 / PPM.00.01 / 2018 with funding source: Budget Implementation Schedule (DIPA) Kemenristekdikti No SP DIPA042.06.1.401516 / 2018 December 5, 2017

\section{Reference}

1. Cooper, M.D. Towards a Model of Safety Culture. Safety Science, 36, 111-136 (2000)

2. Schein, E. H.. Organizational Culture: What it is and How to Change it. In Human resource management in international firms. Palgrave Macmillan, London., ,56-82 (1990)

3. Geller, E. S. Behavior-based safety in industry: Realizing the large-scale potential of psychology to promote human welfare. Applied and Preventive Psychology, 10, 87-105 (2001)

4. Heclo, H. Issue networks and the executive establishment. Public Adm. Concepts Cases, 413, 4657 (1978)

5. Aldrich, H., \& Whetten, D. A. Organization-sets, action-sets, and networks: Making the most of simplicity. Handbook of organizational design, 1, 385-408 (1981)

6. Radin, T. J. From imagination to realization: A legal foundation for stakeholder theory. In Re-Imaging Business Ethics: Meaningful Solutions for a Global Economy , 31-49 (2002)

7. Project Management Institute. A Guide to The Project Management Body of Knowledge Fifth Edition, Project Management Institute (2013)

8. Olander, S., \& Landin, A. Evaluation of stakeholder influence in the implementation of construction projects. International journal of project management, 23, 321-328 (2005)

9. Zhang, L., \& Gao,Y. Safety Culture Model and Influencing Factors Analysis in Construction Enterprises of China. Research Journal of Applied Sciences, Engineering and Technology 4, 3297-3312 (2012)

10. Freeman, R. E., Harrison, J. S., Wicks, A. C., Parmar, B. L., \& De Colle, S. Stakeholder theory: The state of the art. Cambridge University Press. (2010) 